\title{
Transforming Bourdieu's "perfect" economy of symbolic goods into an imperfect one - The moral grounding of water transfers in Khartoum
}

\author{
S. Zug \\ Department of Geosciences, University of Fribourg, Chemin du Musée 4, 1700 Fribourg, Switzerland \\ Correspondence to: S. Zug (sebastian.zug@gmx.net)
}

Received: 3 August 2012 - Revised: 17 January 2013 - Accepted: 8 March 2013 - Published: 3 April 2014

\begin{abstract}
Pierre Bourdieu conceptualizes social action as "instrumental rational". Disinterestedness is only possible as part of an actor's practical logic when the said actor actively or passively misrecognizes underlying interests. In the "logic of logic", this perceived disinterestedness can and must be scientifically reconstructed as a pure economic exchange. Reason-based morality, such as can be found in Kantian philosophy, becomes impossible, and morality becomes an ignored category in Bourdieu's theoretical endeavour. This article's first goal is to locate Bourdieu's approach within moral philosophy, through parallels to Gauthier's Morals by Agreement. An empirical case on water transfers between neighbours in Khartoum reveals the limits of such an approach. This leads to the second goal. By translating Bourdieu's perfect "economy of symbolic goods" into an imperfect one, reason-based morality is integrated into his project, and the relevance of interest for social interaction is curbed, but not denied.
\end{abstract}

\section{Introduction}

Bourdieu's theory of praxis is not, nor was it intended to be, a central contribution to moral philosophy. Bourdieu himself neither aimed to systematize his concepts into a closed theoretical system, as did two important German social theorists of his time: Niklas Luhmann and Jürgen Habermas (Barlösius, 2006:8); nor did he share their interest in morality (e.g. Habermas, 1983; Luhmann, 2008). Instead, Bourdieu stresses the relevance of social theory's empirical grounding: "The analysis of structures and 'mechanisms' acquires its full explanatory power and descriptive truth only because it includes the results of the analysis of schemata of perception, appreciation, and actions that agents [...] make use of in their judgments and practices" (Bourdieu, 1996:1). Paradoxically, while Bourdieu attributes high explanatory power to actors' social practice, he denies the possibility that action could be motivated by conscious reasoning (e.g. Bourdieu, 1990:59). He acknowledges morality - a category which is highly underdeveloped in his theories - only as a relative social structure. Behaving morally is only possible if it is better rewarded than acting immorally. Bourdieu's construction of morality strongly opposes other systems, notably Kantian Deontology, in which moral behaviour is based on the actor's conviction of "doing right", regardless if the action is rewarded.

In empirical research in Khartoum, the different modes of accessing drinking water for individual households were analyzed, including very highly common water gifts between households well connected to the public network and those with poor to no connections. A portion of these free transfers between neighbours cannot be explained by the donors' conscious or subconscious expectations of compensation with economic, social, or symbolic capital. They seem to be altruistic.

Not considering morality as an independent category in the production of social action is a theoretical choice that allows Bourdieu to highlight specific social processes - especially those related to power - over others. Bourdieu was strongly criticized for choosing not to conceptualize morality (Alexander, 1995:130; Boltanski, 2011:20; Honneth, 1986; Lamont, 1992:5; Lempert, 2010:211). By using Bourdieu's concept as an open framework, one can avoid the mistakes, which Lahire claims took place in France. He states that in 
France, "Bourdieu's sociology is either hated (even ignored) or worshipped. If we overlook the former totally negative attitude, we may note that adoration is not appropriate to scientific life" (Lahire, 2011:4). This paper aims to develop morality, at the theoretical level, as a relevant motivation for disinterested action. Aligning theory and empirical findings, however, requires questioning certain of Bourdieu's assumptions.

This paper is a dialogue between empirical findings and Bourdieu's theory of practice. The first chapter briefly presents the empirical context of water gifts in Khartoum and develops a typology of two gift transfers. The second chapter empirically presents the first type and explains how water gifts are motivated by interest in an economy of symbolic goods. This conventional reading of Bourdieu anchors his theory in Moral Philosophy. In the third chapter the second gift transfer is presented and developed as an example of the possibility of disinterested motivation for social action, hence, an empirical critique of the exclusive stewardship of social action by interest. Consequently, Bourdieu's "perfect" economy of symbolic goods is transformed into an "imperfect" one.

\section{Two modes of water sharing between neighbours in Khartoum}

A water gift is embedded in both the social relationship between a donor and a recipient, and in the specific water supply systems of a city. These systems provide water to the donors, who in turn transform the resource into water gifts for recipients, who are perhaps economically or spatially excluded from said systems. Despite being located in the middle of Sahara desert, Khartoum does not suffer from physical water scarcity. Situated at the confluence of the Blue and White Nile, water flows plentifully through the city centre. It is not the physical scarcity that is challenging for public water providers; but rather, providing access to these water resources. Insufficient past investments have resulted in noncomprehensive pipe networks, which in turn translates into high costs and low consumption for a significant share of the population, who resort to purchasing water from vendors.

Strongly aggravated by Sudanese food crises and a civil war, the population in the Khartoum agglomeration grew sharply (up to $8 \%$ annually) from the mid-1980s until the separation of the Republic of South Sudan in 2011. The construction of new networks was heavily neglected until 2005 , resulting in vast areas without access to water distribution networks (Müller-Mahn et al., 2010). In 1991 the case study settlement was established at the western fringe of the agglomeration, providing housing to roughly 2000 forcefully evicted families from different informal settlements. The new neighbourhood was established in a top-down planning process, replicating a standard design with straight streets, common grounds, and certain basic services. At first, the population had access to groundwater via a NGO funded water tower, managed by the public water corporation. Water vendors transported water in donkey carts and sold it directly to the consumers. In 2007, all inhabited plots were connected to a public network. Households were charged a monthly fee for the construction of the pipe and a flat rate tariff for water consumption. The new system has the potential to significantly reduce costs for individual households while increasing compliance and reducing health risks linked to such access. In practice, however, the pipe network does not cover the water needs of a large segment of the population and water gifts have become a very common phenomena in the area.

In 2010, interviews were conducted with households throughout the neighbourhood, political leaders, religious elite, and people working in the water sector, such as water vendors, plumbers, as well as public water corporation staff at various levels. This wide ranging sample allowed a thorough analysis of the neighbourhood's waterscape. For specific gift transactions, guided interviews were conducted with all 57 households of the four clusters; half of which were revisited. This approach provided a dual perspective of the same gift transaction, with an analysis from both the donor and the recipient's point of view within a particular social space.

Gift transfers are widespread in the neighbourhood due to sharp differences in access to the public network between direct neighbours on a very low scale. Being connected to a network does not guarantee access to piped water. Due to insufficient production, uneven topography, and several technical and managerial problems, this particular network leaves many taps dry. Some households have invested in technical modifications of the pipes, such as lowering taps below the surface or installing pumps to suck water out of the network. This has increased water pressure and flow to certain households, but it further reduces water to others. While households who invested in a pump, along with those in the low lying areas, receive water in abundance, others are barely or only partially self-sufficient and many do not receive water at all from the network. The old water vending system fills the gap of water production, leading to the co-existence of public and private-informal water providers. Water from a neighbour's tap or barrels is a significant third source - not in terms of water production and overall availability of the resource within the neighbourhood, but rather as an additional option for households to access water. Water solidarity existed before the network was built, but it increased substantially as a result of the economic reality of water purchases. It is a wellknown fact that in many cities, the water distribution network is much cheaper for consumers than water purchased from the informal sector (e.g. Swyngedouw, 2004:139). This holds true for the study's focus neighbourhood, making it less costly than before to share one's water with others.

Water flows between households are never paid for. Consequently, water originally produced as a commodity becomes de-commodified. By gifting water, the donor shoulders certain costs beyond the strictly economic cost of water. Donors 
also assume costs of social transactions, such as allowing people access into their homes, which in the Sudanese context is a very intimate space protected from the sight of others by high walls.

Water transfers differ in terms of technology, comfort, and social embeddedness. In this typology, a transfer's degree of social embeddedness determines two extremes. A prime example for the first type is water directly pumped through a hose into a neighbour's storage barrels. This transfer is very comfortable for the recipient because it does not require time and physical labour, and the quantity received is generally enough to cover all water needs on a regular basis. These transfers are not only spatially restricted by technical limitations - the pump's strength and the length of the hose - but also by social limitations. Water is only pumped to nearby friends or family members. Transfers between the same households constantly take place, and the relation tends to be initiated by the water rich household. I call this type of water transfer "offered water gifts".

At the other extreme, water is given to people who knock at the door and initiate or actively "request water gifts" from people to whom they are not socially connected. "Requested water" is never provided by hose. Recipients are allowed to fill their jerrycans or buckets. Water obtained thusly requires labour for carrying and often a lot of time since potential recipients must wait for their bucket to be filled, sometimes queuing with other potential recipients. Consequently, requested water is much less comfortable than "offered water".

This article will restrict analysis to these two types of water gifts since they highlight a polarization between a very typical Bourdieusian transaction and a very untypical one. Intermediary types such as taking a jerrycan of water from a close neighbour do exist, but are not discussed here.

\section{A conventional reading of the economy of symbolic goods}

In this chapter, Bourdieu's theory is "applied" rather than being called into question. An analysis of offered water explains gift transactions within an economy of symbolic goods. After the gift's interested logic is reconstructed, the theory of practice is anchored in moral philosophy.

\subsection{Material and symbolic reciprocation of "offered water"}

Access to comfortable water delivery via a garden hose is restricted to households that maintain intense daily social relationships with the pump owner. Donor and recipient are either connected by family ties or by friendships developed during the up to 20 years they were living as neighbours. Some neighbours underline their social ties by leaving a passage open in the wall, which normally divides inhabited plots.
On a material level, free water transfers are not the only transactions that exist: childcare, invitations for tea or to watch television, tools are borrowed, and help is provided for house construction. One family owns a large generator requiring extensive maintenance and manual force to start it. During the day, all male household members work outside the home and cannot start the generator. The neighbour's sons therefore repair and start the generator and benefit from the resulting water production. One family named their youngest son after a generous neighbour, expressing their gratitude to the latter.

Socially distant households normally do not benefit from such transfers with the exception of one family who recently moved into a house. For several months, until they had managed the formalities for receiving their own tap, they received water from a neighbour by hose. The mother of the household explains: "Our neighbour A. saw us trying to stop a donkey cart to buy water. He stopped us and said: 'Don't get water from donkey carts. This is our tap and motor; we operate it every day. Take the water you want.' This was the first time." The initiative to offer water to a new neighbour can be understood within the pump owner's particular vision of this particular stretch of the street. He differentiates between "neighbours" and "social contacts". "Neighbours" are only those people living in his stretch of the street. People from other streets, even those with whom he shares the back wall, are only social contacts because they "are too far to communicate with daily". He argues: "your neighbour is even closer than your brother. If you need anything in happiness or sadness, you will find him.” By providing water to the new family, his goal was to include them into his social network as "neighbours" rather than as merely "social contacts". His vision of the street as a social unit is not shared by all pump owners. In another sector, where neighbours fluctuate often, a pump owner maintains his social network in another street, where his parents live. In his street, he only pumps water to one neighbour with whom he is friends and to his brother, who purchased the plot next to his. He has never offered water through his garden hose to any of the other neighbours, who for the most part do not get a single drop from their taps. Whether a household is offered water or not is consequently strongly related to the existence or the desire for a relationship between the potential donor and his recipient.

The transfers of offered water can be interpreted as a general give and take among neighbours, underlying Bourdieu's "socio-economic" reading of Marcel Mauss' (1990) anthropology of the gift. Gifts in this reading are motivated by expected compensations; hence, they are interest based. If people are asked directly for the compensations of water gifts, they will most likely deny any and refer to a positive image of their society and altruistic values imbedded in their culture. Bourdieu would qualify these statements as a practical logic of the gift transfer, while the analysis of the social researcher would result in a different conclusion and reveal a logical logic. The gift is only the "fiction 
of a disinterested exchange" (Bourdieu, 1977:171), which is made possible by the "leaps of time which is separating the gift from the counter gifts" (Bourdieu, 1977:6). On the one hand, the gift is "experienced (or intended) as a refusal of self-interest and egoistic calculation, and an exaltation of gratuitous, unrequited generosity. On the other hand, it never entirely excludes awareness of the logic of exchange" (Bourdieu, 2000:191). The economic logic for offered water can be justified by the flows of economic and symbolic capital that the recipient returns to the donor in everyday practice. Beyond that, statements such as donors will be able to count on their neighbours in other situations, reveals a certain expectation of compensation as a motivation for letting water flow.

\subsection{Moral and Interests - Anchoring Bourdieu in moral philosophy}

In a Bourdieusian context, offered water gifts can be understood as a form of moral economy. Although Bourdieu neither refers intensively to the work of moral philosophers nor makes morality an explicit element of his theory, his work can be strongly related to these theories.

Moral philosophers have a wide variety of approaches to the relevance of interest in their conceptualizations. Kant completely disconnects morality and interest and argues that "morality itself [is] subjectively considered as a motive, inasmuch as pure practical reason, by rejecting all the rival pretensions of self-love, gives authority to the law, which now alone has influence" (Kant, 2010:78). Hence, to act morally, a person needs to follow social laws regardless of the consequences for the own wellbeing. Analysing Bourdieu's theory from a Kantian perspective would ultimately reveal that there is no moral-based action within logical logic. Although people believe they act morally, within a Kantian definition, in reality, their acts are unconsciously motivated by their striving for interests.

Other approaches in moral philosophy acknowledge that the individual acts as an egoist: Jeremy Bentham's utilitarianism and Thomas Hobbes social contract theory. These approaches, however, cannot be translated into Bourdieu's moral framework since Bentham's (1823) work is mainly restricted to prescriptive ethics, by discussing how people "ought" to act to generate "the greatest happiness of the greatest number", rather than describing what they actually do. Hobbes (1651) argues instead that strong egotism that materializes in a gloomy natural state, which motivates people to subdue each other, can be alleviated by people ceding their power to a sovereign. However, morality is no longer conceptualized at the actor's level, but rather, transformed into positive law (Leist, 2003:5).

David Gauthier's "morals by agreement" (1986) is based on Hobbes' philosophy, but acknowledges that groups of people can move from the natural state into a state of cooperation in order to increase overall welfare without the im- position of rules by a sovereign or any other political actor to prevent them from being reckless. Gauthier's moral philosophy takes a moral descriptive perspective on individual practice, which is in line with Bourdieu's approach to construct a logical logic from the observation of empirics.

Gauthier positions his approach resolutely against Kant: "morality does not emerge as the rabbit from the empty hat. Rather [...] it emerges quite simply from the application of the maximizing conception of rationality to certain structures of interaction" (Gauthier, 1986:10). This departure from people's practice makes Gauthier's approach valuable for developing a moral concept for Bourdieu, because the individual's contributions to the welfare of the group are acknowledged, while individual interests remain the central determinant for social action.

To allow co-operation to emerge, Gauthier argues with evolutionary theory. He develops a typology of two actors. A "straightforward maximizer" "is disposed straightforwardly to maximize her satisfaction, or fulfil her interest, in the particular choices she makes" (Gauthier, 1986:16). A "constrained maximizer", in contrast, looks for long-term benefits and bases her "actions on a joint strategy, without considering whether some individual strategy would yield her greater expected utility" (Gauthier, 1986:167). The strategy of a constrained maximizer is assumed to be evolutionary superior: "The benefits of co-operation ensure that, in any given set of circumstances, each member of a group of reciprocal altruists [i.e. constrained maximizers] should do better than a corresponding member of a group of egoists [i.e. straightforward maximizers]" (Gauthier, 1986:188). In the Hobbesian natural state, cooperation cannot emerge because straightforward maximizers would exploit constrained maximizers. In the language of the gift, they would take gifts, without reciprocating, making co-operation a costly strategy rather than an evolutionary advantage. To prevent this risk, a constrained maximizer will decide not to make gifts to people, who are assumed to violate the rules of the gift, hence, who take more from their neighbours than they return. Instead, when confronted with a person who did not prove trustworthy in previous social practice, "she behaves [as well] as a straightforward maximizer, acting on the individual strategy that maximizes her utility given the strategies she expects the others to employ" (Gauthier, 1986:169). By exclusion of straightforward maximizers, a group of constrained maximizers can maintain their evolutionary benefit of co-operation. People can enter into the group if they prove to be trustworthy, by acting according to the moral framework of the society. In Gauthier's philosophy a transition from an egotistical society to a society built on co-operation becomes possible from the moment a very small group of people starts co-operating and manages to exclude those who would default.

Not only the strong focus on interests and its conceptualization as descriptive ethics qualifies Gauthier's "morals by agreement" as the moral underpinning of Bourdieu's economy of symbolic goods; but also the line of reasoning closely 
corresponds. In the theory of practice, interaction in the social field determines the structure of the respective field, which can include the recognition of disinterestedness. The habitus guides social life along the rules of the social field. Like Bourdieu, Gauthier argues with dispositions that unconsciously guide and mask interested acting: "The just person is fit for society because he has internalized the idea of mutual benefit, so that in choosing his course of action he gives primary consideration to the prospect of realizing the cooperative outcome" (Gauthier, 1986:157). This ethical disposition - a term Bourdieu uses on several occasions without ever developing it (1977:165, 1984:261, 1998:70) - makes constrained maximizers trust others and allows short-term disinterestedness within fields based on mutual co-operation.

By going beyond absolute binary classifications, the grey areas between the two poles can be examined. Thus, people who "tend" to constrain their immediate interests in favour of collective ones, hold higher social positions in social space than those who are known to default. This holds true only within a social framework that rewards good actions and provides the possibility of detection and exclusion of straight forward maximizers. In both projects the interested and morally correct behaviour is connected to uncertainty and risk. For Gauthier the disposition to act morally is based on a strategic choice of the individual, who can calculate the probability of transactions (Gauthier, 1986:42). Since returns are not guaranteed, initiating a transaction needs to be based on trust - a social contract enacted in the respective social field - which confines rational choice, due to incomplete information. Bourdieu argues along these same lines: "the giver's undeclared calculation must reckon with the receiver's undeclared calculation, and hence satisfy his expectations without appearing to know what they are. In the same operation, it removes the conditions making possible the institutionally organized and guaranteed misrecognition" (Bourdieu, 1977:171).

Relating Bourdieu to Gauthier allows us to position Bourdieu's theory within the landscape of moral philosophy. Their definition of morality is practical rather than philosophical while social action is instrumental rational rather than consciously based on reason. A researcher can derive actors' morality by observing social practices and analyze these same social practices through the prism of their morality. This very strong connection is achieved by binding together the very abstract concept of morality with interest as reconstructable empirical phenomena. Gifting water to a neighbour within an economy of symbolic goods is a strategy of capital accumulation. Morals are negotiated as the rules of the particular field, which define how specific actions are to be judged.

\section{The "imperfect" economy of symbolic goods}

Conceptualizing the actor as an interested actor only, is Bourdieu's meta-ethical choice. Why should the individual not base at least part of his action on what he perceives to be "right" according to Kantian moral law, or what he expects to be "good" for others, as in Bentham's ideal of moral actions, while ignoring how his acts will impact his own capital endowments and, consequently, his positions in social fields? Alexander argues that Bourdieu's approach to morality is reductionist. "Neither Bourdieu nor many of his enthusiastic readers seem to understand what a multidimensional social theory actually requires; how individual action and its social environments can be interrelated without reduction; how ideal and material dimensions can be brought into play without sacrificing their autonomy and reducing one to the other" (Alexander, 1995:193).

While a logical logic of hidden interest behind seemingly altruistic behaviour could be reconstructed for offered water gifts, for requested water gifts hidden interests are much more difficult to determine from empirical reality.

\subsection{Requested water gifts require no compensation}

The starting point of the typology of water gifts was social embeddedness. Requested water gifts take place between households which are characterized by the absence of an intensive social relationship; hence, in a social environment which is opposed to the one in which offered water gifts occur. Actors positively responded to requests for water gifts in two types of situations, despite an unfavourable social constellation of the various actors, including both an inexistent social relationship and a negative one. First, households who gift water to each other do not necessarily also know each other. The spatial configuration of a water network's performance does not allow water-poor households to access water from a direct neighbour. Second, in certain areas devoid of water, a minority can be found, who are willing to walk towards distant streets with water and request gifts from those households already gifting water to others. In one house, a small boy took water from a lowered tap. The women of the house allowed the boy to take the water, without knowing to which family he belonged. Gifts to strangers are very prone to profit maximization by the recipient. In Gauthier's terminology, the recipient is likely to turn into a straightforward maximizer since even if he wants to reciprocate, he is not embedded in the same social network in which the gift of water could be compensated.

Even if people are in conflict, requested water transfers still take place. Talking about his direct neighbour, M. states, "we don't want our women to have contacts with just anybody. [...] There are some people who are not good." In this case the negative appreciation of his neighbours is not based on a previous dispute, but on a general stigmatization of any household composed of only single, young men. Despite his 
negative attitude, M. underlines that "they can take water if they want, we leave the hose outside to water the trees and we do not guard it." The social benefit of sharing water with these neighbours seems to be inexistent; especially considering the donor wishes them to move away.

In another street a women expressed her negative view of a neighbouring family, who hardly participated in the street's social activities. She argued that these people were only connected to others from the same ethnic group but were not interested in their neighbours. She stressed that they would only come for marriages or a funerals, considered absolute social obligations. However, the family satisfied their water needs exclusively from water they obtained for free from different neighbours, including this woman who clearly did not appreciate them. She explained why she still provided them access to her water, "even to them you cannot refuse water. We cannot because we have a lot of water. Our behaviour and heart cannot accept preventing these people from taking our water."

In these cases, a reconstruction of the transaction as an economic based logic of logic seems to be impossible. The donor, who is a constrained maximizer, would be exploited because he gives without any return, making "cooperation" uni-directional. In the logic of Gauthier, people would stop giving water to those who do not or cannot reciprocate because of expected losses, which, consequently, would lead to an evolutionary disadvantage. Nevertheless these water transfers take place and question an exclusive economic - in the broader sense of Bourdieu - conceptualization of social reality. Consequently, the positive response to requested water follows a Kantian social law that is not based on interest but on a morally induced disinterestedness, a social awareness for the water needs of others.

\subsection{The capital of moral entitlement - The negation of reciprocity}

Faced with the choice of either completely discrediting Bourdieu's theories or disavowing the empirical data gathered by forcing it to provide some hidden but minimal compensation, a middle path seemed more pertinent. In this chapter, I want to present the possibility of adjusting the theory of practice to incorporate disinterestedness. To understand the coexistence of interested transfers (offered gifts) and truly disinterested water transfers (requested gifts) in the same area, Benedikt Korf's (2007:368) work on moral geography of aid transfers provides an entry point. He argues that post-disaster aid after the Tsunami in the Indian Ocean in 2004 was not free, but - as for offered water - people had to pay a high price by acknowledging the "generosity through the staging of gratitude" (Korf, 2007:367), expressed for example in theatrical performances, songs, and dances for representatives of their donors. Since this gift of aid was not materially reciprocated, the donor exercised symbolic violence over the recipient, leading to the symbolic indebtedness of the beneficiary.
"In unequal reciprocity relations as pertinent in global aid, this expected return for the gift is the acknowledgement of the current order" (Korf, 2007:376), and the victims of disaster become "passive recipients devoid of their status as fellow citizens on this planet" (Korf, 2007).

Korf moves from descriptive ethics of the "is" to normative ethics of the "ought", critically suggesting a shift in aid administration to avoid the gift's humiliating effects. He proposes the establishment of a global emergency fund based on a global taxation that would separate aid from a donor's generosity (Korf, 2007:375). All would be obliged to pay into this impersonal fund to replace current voluntarily gifting directly linked to specific disasters with an obligation. As the rich would pay more than the poor, redistribution of wealth would thus be ensured. Such a system "transforms a beggar or victim to a rightful claimant. Being a rightful claimant to support is something qualitatively very different than being a recipient that simply receives a gift from a generous person" (Korf, 2007:375). While paying into such an aid scheme is a duty grounded in international law, access to it becomes what Korf defines a moral entitlement, "a claim which is independent of the generosity - and thus the virtuous acts - of the donor" (Korf, 2007:347).

On a meta-ethical level, Korf justifies the possibility of the shift of the moral regime in aid transfers with Onora O'Neill's differentiation between virtue and rights based duties. O'Neill argues that both duties are possible motivations for social actions, rather than incompatible elements of different philosophical traditions, a differentiation she rejects as "historically anomalous and not well substantiated" (O’Neill, 1996:2). Present aid flows are virtue-based duties, which are weak because they are commendable but not obligatory. Hence, they underpin Bourdieusian interests that produce indebtedness for the recipient. Under a global fund, duties would be strong because they would be based on rights, making fulfilment compulsory and independent from the interest of the respective donor. However, neither Gauthier nor Bourdieu consider duties in their approach.

For Korf the practical move from virtues to rights in aid transfers is possible, but it requires the auxiliary construction of a global fund to disconnect recipient and donor. However, if global morals had historically developed along a different path and world society had internalized the global right to a decent living, the global fund would not be necessary. The same holds true in the context of Khartoum's waterscape where virtue and rights-based duties co-exist temporally but amongst different constellations of actors.

If we accept that certain social actions are motivated by rights-based duties, which reflect the moral framework of a society without being attached to interests, we can and must take people's arguments about their action more seriously than Bourdieu. The logic of logic cannot be reconstructed at a purely economic level. To comply with the locally universalized norm "of giving water whenever asked", people offered two explanations. For the first, they mention only three 
words that they sometimes can and sometimes cannot further explain: "Grass, water, and fire". These words refer to a Hadith that can be interpreted as forbidding the sale of these elements and as a request for granting access to all (AbuDawood: Hadith Nr. 3470, interpreted by Faruqui, 2001:2). While complying to this religious injunction might be internalized in their habitus, the historic development of this right to water is based on reason in terms of Kantian ethics. The second explanation for their moral behaviour is based on Bentham's utilitarian ideal (discussed previously). They are doing good because they are aware of the importance of access to water in a desert environment and its vital importance. In both cases giving water upon request has become a disinterested moral obligation for those with water and entitlement to support for those lacking water.

What are the implications of such a real disinterestedness for the economy of symbolic goods? Moral entitlements can be integrated in Bourdieu's terminology as capital, the "capital of moral entitlement", which is closely related to symbolic capital. However, it constitutes an inverse or negative symbolic capital since instead of capital wealth it acknowledges the absence or the lack of capital, like poverty, hunger, low levels of education or social inclusion for newcomers, or as in the case of Khartoum, thirst. Having a capital of moral entitlement at one's disposal is a resource like any other capital on the social market. It can be used to directly or indirectly obtain other forms of capital that are lacking and like all forms of ordinary capitals, it gets spent when used. A poor neighbour will lose his capital of moral entitlement to neighbourly financial support, if he receives a big donation or finds a well-paid job. This new situation changes his socially perceived status from poor to non-poor.

Within such an approach, the habitus remains a very important theoretical construction. Moral concepts can be learned and incorporated within dispositions of the habitus. Nevertheless, as Sayer argues, the concept of habitus - as the basic element which guides people's action in Bourdieu's approach - "is a product of sociological disciplinary imperialism, reflecting the discipline's competition with and aversion to psychology and biology" (Sayer, 2005:50). Acknowledging emotions and deliberate reasoning as a motivation for social acting apart from an interested morality and a habitualized disinterestedness, is required to understand the emergence of norms guiding social interaction and social change through idealistic social movements or individuals.

Regardless if specific, real, disinterested, social actions are motivated by individual reasoning or moral dispositions of the habitus, the economic transaction is incomplete because the actor, who fulfils his moral duty, experiences an overall loss. He accepts this loss because of self or society-defined moral duty. Accepting real disinterestedness certainly conflicts with a conventional reading of Bourdieu's economy of symbolic goods, but if we accept that perfect economies can never exist, the "imperfect economy of symbolic goods" allows us to discontinue ignoring the human desire to act ac- cording to what has been learned to be morally right, or even what oneself considers to be good.

\section{Conclusions}

In his early work, when Bourdieu analyzed pre-capitalist societies in Algeria, he made a strong case for the notion of honour. The change in his focus to the context of France, a society which can be assumed to have been much more strongly individualized and influenced by capitalistic profit seeking, could perhaps explain why he did not conceptualize real disinterestedness based on reason and morality as a relevant mode of action in his theory of practice. If we want to apply Bourdieu in contexts, like Khartoum, where unquestioned religious concepts and other moral convictions are a significant factor in daily practice, we either have to accept that we have only a partial grasp of social reality or we must conceive of the economy of symbolic goods as an imperfect economy where people strive to accumulate relative capital and positions, while being restricted by their morally grounded duties.

When social inequality increases, morality can minimize the gap of total capital endowments because it leads to a redistribution of economic and non-economic wealth from those with higher positions to those with lower positions in social space. The social impact of the "capital of moral entitlement", therefore, is opposed to symbolic domination. The total inequality in positions in the social space is minimized in societies that have incorporated a morality of unconditional solidarity.

Acknowledgements. The author is grateful to Olivier Ejderyan, Olivier Graefe, and two anonymous reviewers for their valuable comments.

Edited by: B. Korf

Reviewed by: two anonymous referees

\section{References}

Alexander, J. C.: Fin de siècle social theory: relativism, reduction, and the problem of reason, Verso, 231 pp., 1995.

Barlösius, E.: Pierre Bourdieu. Eine Einführung, Campus Verlag, Frankfurt/Main, 195 pp., 2006.

Bentham, J.: An introduction to the principles of morals and legislation, Volume 1, W. Pickering, London, 281 pp., 1823 [1780].

Boltanski, L.: On critique: A sociology of emancipation, Polity, Cambridge, 200 pp., 2011 [2009].

Bourdieu, P.: Outline of a theory of practice, Cambridge University Press, Cambridge, 248 pp., 1977 [1972].

Bourdieu, P.: Distinction: a social critique of the judgement of taste, Harvard University Press, Cambridge, 613 pp., 1984.

Bourdieu, P.: The logic of practice, Stanford University Press, Stanford, 333 pp., 1990 [1980].

Bourdieu, P.: The state nobility: elite schools in the field of power, Polity Press, Cambridge, 504 pp., 1996 [1996]. 
Bourdieu, P.: Practical reason: on the theory of action, Stanford University Press, 153 pp., 1998 [1994].

Bourdieu, P.: Pascalian meditations, Stanford University Press, Stanford, 256 pp., 2000 [1997].

Faruqui, N. I.: Islam and water management: Overview and principles, in: Water management in Islam, edited by: Faruqui, N. I., Biswas, A. K., and Bino, M. J., United Nations University Press, Tokyo, New York and Paris, 1-32, 2001.

Gauthier, D. P.: Morals by agreement, Clarendon Press, Oxford, 367 pp., 1986.

Habermas, J.: Moralbewusstsein und kommunikatives Handeln, Suhrkamp, Frankfurt, 201 pp., 1983.

Hobbes, T.: Leviathan, or, the matter, form, and power of a common-wealth, ecclesiastical and civil, Andrew Crooke, London, 394 pp., 1651.

Honneth, A.: The fragmented world of symbolic forms: reflections on Pierre Bourdieu's sociology of culture, Theor. Cult. Soc., 3, 55-66, 1986.

Kant, I.: The critique of practical reason, A Penn State Electronic Classic Series Publication, 2010 [1788].

Korf, B.: Antinomies of generosity: Moral geographies and posttsunami aid in Southeast Asia, Geoforum, 38, 366-378, 2007.

Lahire, B.: The plural actor, Polity Press, Cambridge, 280 pp., 2011 [2001].
Lamont, M.: Money, morals, and manners: the culture of the French and American upper-middle class, University of Chicago Press, Chicago and London, 320 pp., 1992.

Leist, A.: Ethik zwischen Hobbes und Kant, in: Moral als Vertrag? Beiträge zum moralischen Kontraktualismus, edited by: Leist, A. and de Gruyter, W., 1-36, 2003.

Lempert, W.: Soziologische Aufklärung als moralische Passion: Pierre Bourdieu, VS Verlag für Sozialwissenschaften, Wiesbaden, 316 pp., 2010.

Luhmann, N.: Die Moral der Gesellschaft, Suhrkamp, Frankfurt/Main, 402 pp., 2008.

Mauss, M.: The gift - the forms and reason for exchange in archaic societies, Routledge, London and New York, 199 pp., 1990 [1923].

Müller-Mahn, D., Beckedorf, A.-S., Abdalla, S. M., and Zug, S.: Wasserversorgung und Stadtentwicklung in Khartum, Geographische Rundschau, 62, 38-44, 2010.

O'Neill, O.: Towards justice and virtue: a constructive account of practical reasoning, Cambridge University Press, Cambridge, 230 pp., 1996.

Sayer, A.: The moral significance of class, Cambridge University Press, Cambridge, 246 pp., 2005.

Swyngedouw, E.: Social Power and the Urbanization of Water: Flows of Power, Oxford University Press, Oxford, 209 pp., 2004. 